\title{
The effects of Oil Price Shock on the Indian Economy - A Study
}

\author{
Dr. Nenavath Sreenu, \\ Assistant Professor in Finance and Accounts \\ Department of Business Management, \\ Indira Gandhi National Tribal University \\ (A Central University), \\ Lalpur, Amarkantak, Anuppur (Dist) \\ Madhya Pradesh -484887, \\ sri_cbm@yahoo.com \\ institutional email: nenavath.sreenu@igntu.ac.in \\ 09425252723
}

\begin{abstract}
The paper examines the effects of crude oil price shocks on the Indian economy development and GDP Growth for the period of 2010 till 2018. The present Indian economy growth has been facing the identical issues of escalating the trade disparity and continuing inflation. In this connection, the study focused on the determine relationship between the speculation and crude oil price impact on the Indian economic development activity and GDP growth and the paper investigated the how oil price variations effect on the Indian economy development through different networks, viz. WPI, CP, IIP, GDP, Monetary policy, trade and investment. The paper used methods an GARCH model and description to tool the volatility on both the oil and stock markets and then developed an extension of the vector auto-regression (VAR) models are also applied to determine the oil price shocks effect on macroeconomic indicators and the outcomes of co-integration model propose that crude oil is pro-cyclical to output, and the paper used VAR investigation to the discrepancy decomposition to capture the linear inter-dependencies among the variables.
\end{abstract}

Keyword: fluctuations, price, WPI, IIP, GDP and shocks

\section{Introduction}

Oil prices play a very considerable role in nation economy development and GDP growth, the present growth layer hovers everywhere the import of oil as India imports more than $70 \%$ of its crude oil necessities. In this research study, an effort has been made to examine 
the impact of crude oil price on the Indian macro economical variable by GDP, Index of Industrial Production (IIP) and Wholesale Price Index (WPI) as the relevant variables. autoregressive Conditional heteroskdasticity $(\mathrm{GARCH})$, description to tool the volatility on both the oil and stock markets and then developed an extension of the GARCH-M mean, vector auto-regression (VAR) has been used to analyse the objective since a direct causal relationship could not be established. Present emerging market investigated made significant advances in understanding the prose and the cons of oil price shocks in India. In specific, most of the research have shown that crude oil price fluctuations do not originate fully from exogenous shocks, such as supply disruptions due to political clashes or synchronised supply constraints in producing nations, but can also be driven by endogenous fluctuations in international economics and GDP aggregates, as well as factors such as economic expansion, existing inflation, currencies changes in rates of interest. In outset, the real rate of oil price ought to be reflected as endogenous to economic fundamentals analysis. The Unpredictability in oil prices has a significant effect on stock values and profits of the developing economy and GDP growth. Moreover, according to the argument of nenavath sreenu (2016), if unexpected oil price fluctuations are able to shocks the real economy development of nation and change in the GDP growth due to the consumer and firm behaviour, then the results of present paper will effect on the Indian and world stock market. In this view, oil price fluctuations should be carefully examined and the paper use an experimental framework grounded on a two-stage method in order to evaluate the effect of oil price fluctuations on the Indian economy development depending on the underlying source of the shock. The paper sampling analysis coverage for the period from 2010 to in this connection, and besides contribution of the current research paper is that the estimate our statistical tool with monthly data. Indeed, as the study will explain below, our empirical set up profoundly relies on delay constraints that are economically credible only at monthly frequency. More precisely, the paper finds that important huge and persistent fluctuations in the real price of oil of market from 2010 to 2018 have been related with the cumulative effects of crude oil demand rather than supply of oil shocks. The circumstance that flow supply quantity disruptions have had minor effects on the real oil price on the stock market does not mean that political dealings in the nation do not matter. On the conflicting, these kind of situation have exaggerated the real oil price by fluctuating expectations about forthcoming shortages of oil supply comparative to oil demand. In our data analysis these anticipations are captured by shocks on defensive demand for oil.

Indian economy is a world seventh largest economy the research paper studied main important key receiver of deteriorating crude oil prices from 2010 to 2018 . An examination by this research paper, more than few a year back, had directed that virtually the whole decrease of about $0.8 \%$ of the GDP in India's fiscal deficit of the nation from 2010 to 2018 could be accredited to the sharp reduction in crude oil prices. Inferior crude oil prices also subsidised to the contracted present account deficit. The largest advantage of the reduction in oil prices was apparent in slenderer identical deficits. From 2010 onwards the pass-through of the reduction in crude oil prices to retail was inadequate, the straight impact on the Indian economy is inflation measured by consumer price index (CPI) was low-key. The researcher explains very preciously, though, in progress retrogressive about two years ago and have collected statistical information in the previous few months back. As in contradiction of a normal price of US Dollar 46.2 per barrel for the Indian linen basket of crude oil in the financial years 2016, its sprinkler to US Dollar 56.4 per barrel in the year financial year 2018 and normal US dollar 65 per barrel in the $1 / 4$ quarter of financial 2018. In the continuation of the study it could be draw the conclusion of the study that higher crude oil prices will unfavourably affect the identical 
deficits fiscal and present account deficit of the Indian economy, which will have overflow influence on the monetary policy and investment behaviour in the nation economy.

\section{Theoretical Framework}

Present, the research paper may find the adverse influence of increase in crude oil prices. A precipitous fall in the present financial accounts leads to additional deteriorating of the capital budgets, which, in opportunity, will additional worsen the equilibrium between savings money and investments. Also, dropping GST revenues and other unimportant factors will additional depreciate the Capital budgets. Outstanding to the economic crisis in Turkey, China and Europe, where the capital budgets have surprized, there is a huge disparity between savings amount and investments plan. These kind of imbalances of saving and investment carry on deteriorating since the rising crude oil prices due to that reason in India petrol price hiked, which loom to thrust the Indian economy into much profounder crisis and inflation. When any nation has a static insignificant currency exchange rate and there is also an output results gap, there is a rise in oil prices indications to a rise in the general wholesale price altitudes. According to a reserve bank of India sources (2015), for each unit US dollar upsurge in crude oil price level, the research paper which has selected variables like, IIP, WPI, GDP and Economy growth, with help of these variables the research study has estimated what are impact on the Indian economy. According to Kaushik Bhattacharya (2005) has explored the impact of rising in oil price on inflation. The research studied the instrument of rising in the prices of crude oil products on the prices of other merchandises and the outcome in India. Due to all other factor impact and oil importing countries challenged the hazard of oil shock; India, being a foremost oil importer, was particularly affected.

The many studies related to crude oil price explored and studied on the affiliation among oil prices, GDP, interest rate and real economic accomplishments particularly for the industrialised country invented by Darby (1982) and Hamilton (1996). Bjorn land (2009) surveyed impact of oil price shocks for oil exporting country like Norway and in a dissimilar paper Bjorn land (2000) investigated the pivotal role of oil price surprises on GDP growth, economic development and employment for UK, Germany, USA and Norway, using a SVAR model. According to Hamilton (1996) and others others research papers drawn-out their effort to model asymmetric answers of positive and negative oil price surprises to the one country economic development and GDP growth. While mainstream of the research studies are grounded on the economic development, there are many research papers investigative the important of oil prices for emerging countries like India. However, the output remains uncertain. Further Hidhayathulla (2014) has given his own view on the crude oil price impact on the Indian economic development, the study has originated that oil prices considerably affect the Indian exchange rates on GDP development although in the view of Kaushik (2014) illustrated that the there is no measurable effect of oil price change on the real exchange rate between the Indian rupee and the USD. In the connection of above research studied the present paper is going to explore based on the empirical study the possessions of modernisations to oil prices and interchange rate on the Indian development of economy, the study adopted a minor open economy structural vector auto-regression (SVAR) model. This model is founded on Kim and Roubini (2000) and is altered to fit the Indian economy development. The research study model from Barnett (2016) is exposed to appropriate to the Indian economy development indication along with as it is able to recognise all the shockwaves of crude oil price appropriately. The research study prepares desire response examination to measure the quality 
of the model in relationships of recognising diverse shocks. Having done that this also gives us detailed approximations of the influences of each shock on crude oil prices, the results, interest rate, exchange rate and investment. The study accomplishes modification disintegration examination to see how much of the oil price and exchange rate can elucidate the instabilities in the oil prices, outcome, interest rate and liquid currency. Finally adopting the antique decomposition analysis, the research study characteristic, the role of each astonishment in illumination dissimilarities in oil prices, the outcome and exchange rate.

According to Kim (2005) examine the disproportionate and proportionate impact between macroeconomic variables and rising the oil price shock. In his research study outcomes deep-rooted that the price has a disproportionate effect on the macroeconomic variables. And further according Lee (1995) has found that the volatile upsurge of oil prices is more disadvantageous to macroeconomic development indicators than the recurrent but anticipated price fluctuated. The wholesale oil price change constructs the ambiguity in market, foremost the stockholders and customers to fail the confidence in their upcoming investment and depletion prospects (Edelstein and Kilian, 2009; Raza 2016). The research study experiential indication of authorising resilient negative affiliation between oil price shock and business predisposition to expand are dependably found in collected works since 1973. According to Archanskaia (2011) surveys the influence of oil price to global economy. He has analyses the influence of oil price shock between 1970-2006 through supply-driven shock and demand driven shock. They emphasis on data from countries that are main consumers of oil since those countries are subjective by the oil price shockwaves. The statistics of GDP is acquired from allowance the average of real GDP growth from the nations that consumer of the oil. The research study outcomes show that the supply-driven shock and basis negative impact to the macroeconomic of the countries while in the period of 1992-2006, the oil shock occur because of the demand-driven shock which does not suffer the macroeconomic of the countries. Chang and Wong (2003). He has examined the long run relationship between oil price shocks to the economic development of Singapore. With help of the Vector Error Correction Model (VECM) is applied. They use three-monthly data between 1978 Q1 and 2000 Q3. The outcome of the paper from instinct reply and inconsistency decomposition disclose that oil price shock makes available a negative impact to the Singapore economic development.

According Ahmad (2013) literature review that the important frequencies of communication between oil price and economic development activity have been recognised in economic theory, specifically, the characteristic supply-side effect, the demand side effect, the affluence transmission effect, the real equilibrium effect, the inflation effect, the segment modification effect and the unanticipated effect. Other side the researcher Brown and Yucel (2002) has explain about the preserve that the supply-side network best elucidates the opposite relationship between oil price and outcome and the positive relationship between oil price and inflation. according to Ewing and Thompson (2007) examined the oil-macroeconomic dynamic forces by investigating the recurrent co-movements of crude oil prices with customer prices, joblessness, outcome and stock prices using unrelated time series filtering methods. The outcome of the obtained in their research paper highpoint important cyclical connections between oil prices and economic development cycles in both the labour and financial markets and other side the research illustrated that the Ozlale and Pekkurnaz (2010) establish that in the short term, an unpredicted upsurge in oil prices reasons the change in the present account ratio to fall in the Turkish economy crises even after monitoring for outcome gap and interchange rate of currency. According to Hassan and Zaman (2012) reviewed that an adverse and important relation between oil prices and trade balance together in short run and long run in the framework of Pakistan's economy development. 
According to Zhang and Wei (2010) demonstration that there is a long-term symmetry between oil price and gold prices and the crude oil price change linearly Granger causes gold price volatility. India being an oil-importing economy development, an intensification in international oil prices shocks can prime to inflation and exchange rate shocks. The stockholders may use valuable metals to privet against inflation and currency hazard. Accordingly, long term requirement of gold prices on oil prices is also predictable (Jain and Ghosh, 2013). According to Maghyereh and Akttam (2004) denied the view of Jungwook and Ronald (2008) by using VAR method and determined that the crude oil price shocks have no important impact on index returns in Indian market. In the view of Ono (2011) has investigated that the effect of crude oil prices on BRIC countries stock markets. In his research paper drawn the interpretation of that the stock expected returns of India, China and Russia have an optimistic influence and the Brazil stock market returns do not demonstration any statistical important. In an examination by Ready (2013), has determined that the crude oil demand shocks interconnected with the confidently with stock market returns, though, oil supply in the BRIC counties has an undesirable relationship with stock market returns. According to Akomolafe and Danladi (2014), examined the relationship between company's stock market returns and differences in crude oil returns. The researcher has adopted the co-integration and VECM model to analyse the affiliation. The outcome showed that the banking sector replies regularly to modification in oil price. In an examination by Kollias (2011), he has found in his research paper the covariance between market returns and oil expected returns in conflict time period.

According to Jones and Kaul (1996) have explore the research investigation about the influence of oil price on the more than a few stock markets such as U.S, IK Canada, and Japan. In his research article the researcher has establish relationship between the various related variables of economic development indicators and based on the outcomes for these countries. They experiential that the consequence of oil price on the U.S. and Canada actual cash flow is important while for U.K and Japan is not important. In the Moreover, Sadorsky (1999) has showed in his research paper about the consequence of oil price in the U.S.A. stock market which recommended that oil price has the substantial effect on the stock market. According to Faff, Brailsford (1999) explore in their research article have extended the identical outcome as Sadorsky (1999) for Australia. Papapetrou (2001) he is also has initiate the same assumption for Greek. According to Park and Rotti (2008) acknowledged that oil price instability has adverse effect on oil wholesaler and positive effect on oil exporter countries.

\section{Estimation of methodology}

The study has adopted methodology based on quantitative and analytical research. The analysis is done mainly by statistical tools and econometrics methods to find out relationship, cause and effects between the dependent and independent variables, also empirical relationship of the variables based on the objective followed with autoregressive Conditional heteroskdasticity $(\mathrm{GARCH})$, description to tool the volatility on both the oil and stock markets and then developed an extension of the GARCH-M mean, vector auto-regression (VAR) has been used to analyse the objective data. The Secondary information has been collected from the Indian crude basket prices, Central Statistical Organization (CSO) data of Indian Economy, Petroleum Planning and Analysis Cell (PPAC) data, whole sale price index, Inflation rate and GDP growth RBI reports, Indian Economic survey reports, reports and websites. The paper consist the theoretic model is estimated with the Bayesian approach. The fascinations of this 
method are by now well known in the economic secondary information. It furnished a full description of the data generating process and allows for appropriate measurement testing. In specific, this model permits us to formalise the use of previous information coming either from micro-econometric studies thereby arrange a categorical link with the previous secondary data collected from reports. It also, as a significance, reveals the underlying shocks. The paper estimates the mode of the subsequent dissemination by exploiting the log posterior function, which associations the prior information on the parameters with the likelihood of the data.

\section{Results and analysis}

The paper data analysis results will be obtainable in a way that after each outcome an analysis will be demonstrated. This was selected in order to make more clarity in this research paper. Present this paper disclosed and to see the comprehensive of data analysis of the regressions results, Vector Auto Regressive values, co-integration analysis, unit root test and Variance Decomposition Analysis.

Table- 1: Regression model results - oil price fluctuation and impact of the Indian GDP

\begin{tabular}{|l|l|l|l|l|}
\hline Crude oil price increasing & Lag & Coefficient & t-value & p-value \\
\cline { 2 - 5 } & 1 & -0.00568 & -1.03865 & 0.02568 \\
\cline { 2 - 5 } & 2 & 0.01275 & -0.05236 & 0.45863 \\
\cline { 2 - 5 } & 3 & -0.00658 & 0.52361 & 0.00568 \\
\cline { 2 - 5 } & 4 & -0.04537 & 1.00689 & 0.53692 \\
\hline 5 & 0.00058 & -0.56289 & 0.14523 \\
\hline \multirow{5}{*}{ Crude oil price decreasing } & 6 & -0.00047 & -2.36058 & 0.00568 \\
\cline { 2 - 5 } & 7 & -0.45870 & 1.58672 & 0.00056 \\
\cline { 2 - 5 } & 8 & 0.04389 & -0.23698 & 0.12587 \\
\cline { 2 - 5 } & 9 & 0.47381 & 0.56987 & 0.00003 \\
\cline { 2 - 5 } & 10 & -0.00246 & 1.02387 & 0.02135 \\
\cline { 2 - 5 } & Lag & Coefficient & t-value & p-value \\
\cline { 2 - 5 } & 2 & 0.04587 & -2.00691 & 0.23569 \\
\hline 3 & -0.04578 & 0.04576 & 0.00457 \\
\cline { 2 - 5 } & 4 & -0.07698 & -0.00586 & 0.56980 \\
\cline { 2 - 5 } & 5 & -0.00457 & 0.20356 & 0.01567 \\
\cline { 2 - 5 } & 6 & -0.14756 & -0.00078 & 0.05689 \\
\cline { 2 - 5 } & 7 & 0.00095 & 1.02356 & 0.56128 \\
\cline { 2 - 5 } & 8 & -0.01475 & -2.56890 & 0.51973 \\
\hline & 9 & 0.04382 & 0.12547 & 0.56983 \\
\cline { 2 - 5 } & 10 & -0.01438 & 0.24385 & 0.03751 \\
\hline
\end{tabular}

Source: SPSS output

The Regression model disclosed the results it can't be appreciated that the p-values of each t-statistics are not significant for the Indian economy and GDP development activity. The study shown the results under a 5\% significance level, which is not intersecting in line with the economic development activity. However, for the research paper results are at an insignificance level of 0.02135 in the tenth lagged when the price of oil increases. It can be experiential that the sixth lagged indicated the significance when price reductions if the research study founding intersect line with the significance level of $10 \%$. The analysis at $5 \%$ level of significance value, the selected variables impact cannot be insignificance for the Indian GDP growth, implication that permitting to the regression model and the sample techniques period from 2010 to 2018 
oil price variations have effect on Indian GDP growth and hamper the development of economy activity. The data analysis results from the above table has shown the pattern of negative correlations for GDP and economic development. From the table no -1 , the study highlighted the how it has rose an adverse correlations relationship among the DGP, Crude oil price and economic development activity from a price rise while a price reduction has as consequence a negative impact. According to the regression analysis and the sample technique period has considered from 2010 to 2018 . The study is a complex to oil variations. A crude oil price rise will ultimately have a negative impact on results and a price decrease a positive impact will be there on development of nation.

The Vector Auto Regressive estimates, R-Squared and the Akaike Information Criterion and Schwarz criterion of oil price shocks and impact of Indian economy and GDP Growth are shown in the following table:

Table -2: Vector Auto Regressive values:

\begin{tabular}{|l|l|l|l|l|l|}
\hline & GDPX & WPIX & CPX & IIPX & $\begin{array}{l}\text { Indian } \\
\text { Economy }\end{array}$ \\
\hline GDPX (-1) & -0.568 & -0.487 & -0.967 & -0.468 & -0.927 \\
\hline & $(0.2568)$ & $(0.4587)$ & $(0.6732)$ & $(0.8692)$ & {$[-1.2340]$} \\
\hline & {$[-1.6803]$} & {$[-3.5601]$} & {$[1.5680]$} & {$[-2.5304]$} & $(-1.5637)$ \\
\hline WPIX (-1) & -0.5911 & -0.5390 & -0.4216 & -0.8431 & -0.1375 \\
\hline & $(0.23567)$ & $(0.4685)$ & $(0.5196)$ & $(0.7549)$ & $(0.5318)$ \\
\hline & {$[0.2538]$} & {$[-1.2379]$} & {$[1.7589]$} & {$[-2.5684]$} & {$[-0.5316]$} \\
\hline CPX (-1) & -0.8965 & -1.2356 & -0.4689 & 0.3794 & -0.3186 \\
\hline & $(0.4589)$ & $(0.4012)$ & $(0.1678)$ & $(0.1496)$ & $(0.2751)$ \\
\hline & {$[-1.2356]$} & {$[-0.8976]$} & {$[-1.5076]$} & {$[-0.4037]$} & {$[-0.1973]$} \\
\hline IIPX (-1) & -0.7937 & -1.7267 & -0.8679 & -0.2671 & -0.4856 \\
\hline & $(0.4578)$ & $(0.4976)$ & $(0.9671)$ & $(0.4573)$ & $(0.3106)$ \\
\hline & {$[-0.4570]$} & {$[-0.5691]$} & {$[-1.8317]$} & {$[-0.4634]$} & {$[-1.1201]$} \\
\hline C & 0.4581 & 1.5692 & 0.8579 & 0.1673 & 0.5346 \\
\hline & $(0.5469)$ & $(0.7596)$ & $(0.4573)$ & $(0.4578)$ & $(0.2431)$ \\
\hline & {$[1.3761]$} & {$[2.5683]$} & {$[1.4670]$} & {$[3.4570]$} & {$[2.4210]$} \\
\hline
\end{tabular}

Source: SPSS output (The values showing that the Standard Errors and t-Statistic)

Table-3: R- Squared and The Akaike Information Criterion and Schwarz criterion values:

\begin{tabular}{|l|l|l|l|l|l|}
\hline & GDPX & WPIX & CPX & IIPX & $\begin{array}{l}\text { Indian } \\
\text { Economy }\end{array}$ \\
\hline R Squared & 0.23568 & 0.04879 & 0.56944 & 0.88945 & 0.42561 \\
\hline Adj. R Squared & 0.98756 & 0.56895 & 0.45896 & 0.86597 & 0.12157 \\
\hline F. Statistics & 28.4572 & 19.4578 & 4.2568 & 4.5671 & 3.12452 \\
\hline Long likelihood & 68.2356 & 84.2356 & 24.2378 & 93.4576 & 63.2564 \\
\hline Sum of square residual & 0.00356 & 0.23510 & 0.02568 & 0.15476 & 0.14785 \\
\hline Schwarz Criterion (SC) & -3.4586 & -2.4578 & -6.4216 & -5.3248 & -3.2568 \\
\hline S.E. Equation & 0.00245 & 0.00487 & 0.00846 & 0.02563 & 0.00546 \\
\hline Mean dependence & 0.00235 & 0.00457 & 0.02375 & 0.00458 & 0.01247 \\
\hline $\begin{array}{l}\text { Akaike Information Criterion } \\
\text { (AIC) }\end{array}$ & -2.3658 & -4.5689 & -3.1245 & -1.2567 & -2.35674 \\
\hline $\begin{array}{l}\text { Standard deviation } \\
\text { dependence }\end{array}$ & 0.10964 & 0.50321 & 0.04610 & 0.01457 & 0.04576 \\
\hline
\end{tabular}

Source: SPSS output 
The above table No 2 and 3 shown the results of Schwarz criterion and Akaike Information Criterion are the least for a lag of two as a result representative that a lag of two phases is the optimal. The high value of R-squared for IIP and GDP, Indian Economy directs a noble fit amongst these variables against CPX, IIP and WPI. The F values also show a significant association at $10 \%$ level of significance. Hence, the study may say that there survives a significant affiliation between the Indian economy and GDP growth, WPI, IIP, and crude oil price. The results indicated in table no 2 , that the any constructive variation in the crude oil price has a speedy adverse influence on the increase in the GDP and WPIX while it affects the CPX positively. While GDP and WPI expression signs of fluctuating decline certain time period, IIP, after a positive increase, revenues to its innovative value within the during period of time. A fluctuation of oil price when particular to IIP effects on Indian economy and GDP in the same method since the fact that IIP also comprises other relationships, apart from oil price which establish approximately $6.23 \%$ weight values but also ultimately impacts other product related values.

The study has been find out that the investigation from table no 3, follows with the conversation that the structure does have a long term relationship among the selected variables, and has an consequence for more than 8 quarters with related to Indian economy development, GDP and IIP while for WPI, the structure of returns to its innovative value instantaneously as associated with other variables, Any unexpected alteration in the price of oil has the capability to influence the trade growth adversely. It also causes a very high increased in the IIP. Overall, fluctuation in oil price, IIP increase and deteriorating WPI effect on the Indian economy and GDP growth negatively and even if the instinct or shock of oil price is short term, it has an extended long-term impact on the Indian economy and GDP growth.

\section{Results of Co-integration analysis of crude oil price fluctuation impact Indian economy}

From the table no -4 , the research paper declares the results that there are co-integration vectors. The table includes the ranks values, eigenvalues, critical values and trace statistics. The selected variable is that the number of co-integrating association is equivalent to $r$ value, which is the shown in the tables the "maximum rank" column of the results. The alternative variable values are that there are more than $r$ co-integrating relationships. In this connection, the selected variables values are insignificant if the critical value is the lesser than the trace statistic. The research paper begins by testing the variables determine value $r=0$, if its insignificance, repeat for same variable $r=1$. While a selected variable is not insignificance, stop to testing or analysis there, and that the value of $r$ is commonly used determine or estimate of co-integrating association of which the study selected among variables. In other side, the selected variables value $r=0$ is insignificance at the $5 \%$ level $(37.86915>13.56828)$. Then the study carries on to the selected variables $r$ value became a $1(r=1)$.

Meanwhile the suggestion statistic value is greater than its critical value $(29.47864>$ 12.45763), the research study disclosed the value insignificant of above mention variables in the table. Moreover, the study continues to the $r=1, r=2, r=3, r=4$, etc. Lastly, when $r=5$, the suggestion statistic value is less than its critical value $(38.17682<15.47834)$ and the study not to test the variable significant values, which means the research paper can draw conclusion that there are 5 co-integration vectors in the present model. At the present of co-integration vectors model and it explain that the selected variables values have a long run relationship and 
the research paper should continue to use VECM (Vector Error Correction Model). VECM limits the long run affiliation among variable of the study so that convergent the co-integration affiliation but still let the vibrant variations in short run time. The vocabulary of co-integration is acknowledged as error correction, meanwhile if there is unconventionality in long run symmetry will be modified progressively with the short run alteration.

Table-4: Co-integration test of Johannsen model

\begin{tabular}{|c|c|c|c|c|c|}
\hline \multicolumn{6}{|c|}{$\begin{array}{l}\text { Trend: Constant } \\
\text { Sample: } 2010-2018 \\
\text { Number of observations }=38 \\
\text { Lags }=4\end{array}$} \\
\hline $\begin{array}{l}\text { maximum } \\
\text { rank }\end{array}$ & LL & eigenvalue & $\begin{array}{l}\text { trace } \\
\text { statistic }\end{array}$ & $\begin{array}{l}\mathbf{5 \%} \\
\text { critical } \\
\text { value }\end{array}$ & $\begin{array}{l}\mathbf{1 \%} \\
\text { critical value }\end{array}$ \\
\hline 0 & 124.86938 & 0 & 37.86915 & 13.56828 & 15.86957 \\
\hline 1 & 210.45872 & 0.56893 & 29.47864 & 12.45763 & 13.73594 \\
\hline 2 & 103.56813 & 0.14378 & 23.47819 & 10.46834 & 11.25374 \\
\hline 3 & 53.14683 & 0.58617 & 21.61837 & 9.48370 & 10.75863 \\
\hline 4 & 79.27648 & 0.43791 & 20.95176 & 8.47358 & 9.34687 \\
\hline 5 & 127.45615 & 0.53781 & 19.76814 & 7.45862 & 8.49372 \\
\hline 6 & 183.16728 & 0.183760 & 16.17682 & 5.47834 & 6.48376 \\
\hline 7 & 91.83915 & 0.439876 & 0 & 0 & 0 \\
\hline
\end{tabular}

Source: SPSS output (Point out there is 5 co-integrated vector)

Having co-integration, the study continues to shape the VEC model. VEC determine and estimates the parameters of co-integrating VECMs. The research paper examines the foremost points in the VECM model; the short-run coefficients and the parameters in the cointegrating equations. Since the study use lag 5 as the number of lags that the study acquires from preceding method, the study has four matrices of short run coefficient.

Table- 5: Results of Unit Root Tests for India

\begin{tabular}{|l|l|l|l|l|l|l|l|l|}
\hline $\begin{array}{l}\text { Statistics } \\
(\text { Level })\end{array}$ & In IR & Lag & In SI & Lag & In OP & Lag & In IP & Lag \\
\hline$\tau_{\pi}(\mathrm{ADF})$ & -1.56 & $(0)$ & -1.86 & $(2)$ & -2.01 & $(0)$ & -1.53 & $(1)$ \\
\hline$\tau_{\mathrm{T}}(\mathrm{ADF})$ & -2.42 & $(0)$ & -0.47 & $(2)$ & -0.47 & $(0)$ & -0.67 & $(1)$ \\
\hline $\mathrm{T}(\mathrm{ADF})$ & -0.45 & $(5)$ & -2.68 & $(2)$ & -1.89 & $(0)$ & -2.45 & $(1)$ \\
\hline$\tau_{\mathrm{T}}(\mathrm{PP})$ & $-1.17^{*}$ & $(5)$ & -1.89 & $(9)$ & -2.57 & $(3)$ & -1.37 & $(4)$ \\
\hline$\tau_{\pi}(\mathrm{PP})$ & -0.42 & $(4)$ & -0.67 & $(9)$ & -0.43 & $(4)$ & -2.41 & $(4)$ \\
\hline $\mathrm{T}(\mathrm{PP})$ & $-2.67^{*}$ & $(6)$ & -0.73 & $(10)$ & -1.08 & $(7)$ & -0.05 & $(5)$ \\
\hline $\begin{array}{l}\text { Statistics } \\
(\mathrm{Difference}\end{array}$ & $\Delta$ In IR & Lag & $\Delta$ ln SI & Lag & $\Delta$ in OP & Lag & $\Delta$ In IP & Lag \\
value $)$ & & & & & & & & \\
\hline$\tau_{\pi}(\mathrm{ADF})$ & $-3.52^{*}$ & $(2)$ & $-2.67^{*}$ & $(1)$ & $-12.67^{*}$ & $(2)$ & $-3.02^{*}$ & $(0)$ \\
\hline$\tau_{\mathrm{T}}(\mathrm{ADF})$ & $-0.56^{*}$ & $(2)$ & $-0.57^{*}$ & $(1)$ & $-17.19^{*}$ & $(2)$ & $-0.09^{*}$ & $(0)$ \\
\hline $\mathrm{T}(\mathrm{ADF})$ & $-2.83^{*}$ & $(2)$ & $-1.39^{*}$ & $(1)$ & $-9.43^{*}$ & $(2)$ & $-2.41^{*}$ & $(0)$ \\
\hline$\tau_{\mathrm{T}}(\mathrm{PP})$ & $-1.37^{*}$ & $(3)$ & $-3.19^{*}$ & $(3)$ & $-3.11^{*}$ & $(5)$ & $-1.17^{*}$ & $(1)$ \\
\hline$\tau_{\pi}(\mathrm{PP})$ & $-4.71^{*}$ & $(4)$ & $-1.57^{*}$ & $(3)$ & $-0.45^{*}$ & $(5)$ & $-4.57^{*}$ & $(1)$ \\
\hline $\mathrm{T}(\mathrm{PP})$ & -2.59 & $(4)$ & $0.59^{*}$ & $(3)$ & -6.89 & $(5)$ & $-0.93^{*}$ & $(1)$ \\
\hline
\end{tabular}


Source: output of E-VIEWS 7.0. (IR -interest rate, SI- Stock Index, OP- oil price, IP- industrial production)

The Outcomes of unit root tests with this connection of the India economy and GDP Growth are obtainable in Table No -5. It is perceived that in the item of InIR variable values, the selected variables of a unit root cannot be insignificance when including tendency and intercept, only intercept, and neither tendency nor intercept. This outcome of the above table is the same in both ADF and PP tests. Though, when lnIR is differenced, the research paper see that the variables values of a unit root can be insignificance in all of the model decisions; in this view the paper drawn the results in both ADF and PP assessment statistics are statistically positive or significant. Consequently, the paper drawn the conclusion that $\ln I R$ in the economic aspect of India is non-stationary at levels of statistics values but become stationary at differences of statistics values; this stage the research study has given positive suggestion that $\ln I R$ in the India is integrated of the first order. The paper has discussed about the variable of InSI with reference to the Indian economy and GDP growth is $\operatorname{lnSI}$ where the variables with related to InSI of a unit root cannot be shows insignificance values when including tendency values and intercept in both ADF and PP assessments. While the selected variables of InSI of a unit root it has chance to be rejected variables values when containing with no tendency value and no intercept, it is significant to reminder that the tendency and intercept coefficients values in the most common model are statistically positive or significant values in the normal distribution. Hence, the research paper drawn the conclusion that $\operatorname{lnSI}$ in the India is a non-stationary variable. In this junction the research paper gives this suggests that like $\operatorname{lnIR}, \ln S I$ are also assimilated of the first order. The research study finally has discuss about the lnIP and $\operatorname{lnOP}$ are consider for determining the oil price values impact on the Indian economy and GDP growth with the reference of Indian Context, as the outcome of the above table the results are the same with the case of $\operatorname{lnIR}$, which means that the selected variables for this study with reference of a unit root cannot be shown the insignificance values at levels of statistics but can be rejected some variables at differences level of statistics of $\operatorname{lnOP}$ and $\operatorname{lnIP}$. In this connection, the paper has drawn the conclusion that they are also integrated of the first order. For this analysis both test of ADF and PP unit root statistics in this research paper have showed that $\operatorname{lnIR}, \ln S I, \operatorname{lnOP}$, and $\operatorname{lnIP}$ are all variables integrated of the first order, which means that they become stationary only when they are difference.

Table- 6: Variance Decomposition Analysis of Indian economy, GDP, Inflation, interest and real exchange rate

\begin{tabular}{|l|l|l|l|l|l|l|}
\hline \multirow{5}{*}{ India } & Years & Inr Indian Economy & Inrex $_{\boldsymbol{t}}$ & lnrinf $_{\boldsymbol{t}}$ & lnrint $_{\boldsymbol{t}}$ & lnrGDP $_{\boldsymbol{t}}$ \\
\cline { 2 - 7 } & 2010 & 1.235 & 0.568 & 8.276 & 15.326 & 0.536 \\
\cline { 2 - 7 } & 2011 & 1.986 & 6.369 & 8.967 & 14.586 & 3.562 \\
\cline { 2 - 7 } & 2012 & 2.458 & 6.745 & 10.756 & 18.276 & 5.235 \\
\cline { 2 - 7 } & 2013 & 2.687 & 8.576 & 13.458 & 16.496 & 4.568 \\
\cline { 2 - 7 } & 2014 & 3.568 & 8.914 & 13.973 & 21.854 & 5.869 \\
\cline { 2 - 7 } & 2015 & 4.258 & 9.867 & 14.475 & 22.586 & 6.458 \\
\cline { 2 - 7 } & 2016 & 5.687 & 9.478 & 16.853 & 24.865 & 7.568 \\
\cline { 2 - 7 } & 2017 & 6.458 & 11.253 & 18.425 & 23.458 & 9.532 \\
\cline { 2 - 7 } & 2018 & 6.867 & 12.753 & 21.284 & 26.485 & 9.867 \\
\hline
\end{tabular}

Source: output of E-VIEWS 7.0

The outcome of table no - 6, the variance decomposition for Indian economy, inflation, interest rate, real exchange rate and real GDP for the period of 2010-2018 is shown in the above table. Since this examination is proposed to investigate in predominantly oil price fluctuation on Indian economy and GDP growth consequently explore the controlled to the estimate error variances only inferred by oil price changes. The projected effects disclose that oil price 
shockwaves elucidate unlike differences in the selected variables with related to Indian economy and GDP growth. The crude oil price shock account range of above mention variables in the above table for $1.235-6.867 \%, 0.568-12.753 \%, 8.276-21.284 \%, 15.326-26.485 \%$ and $0.536-9.867 \%$ of variation in real output and impact on the inflation, interest rate, GDP, economic development and exchange rate correspondingly variation over the period of 20102018 in India. It suggests that oil price inventions have considerable effect on these economic development variables during the time of 2010 to 2018.

\section{Conclusion}

Presently the research paper has drawn the conclusion based on the data analysis and findings, based on the outcome of the table no 1 the study found that the huge variations is there crude oil prices fluctuation and great draw back and insignificant impact on the economic development activity (2010 - 2018). In this concern, policymakers, financial analyst and economists have paid close thoughtfulness to alterations in internationally traded crude oil prices and apprehensive about the prospective impact of oil price shocks on Indian economic development activity. The study has examined the how the effect of crude oil price changes on the Indian economy fluctuates, the paper finds the fluctuation of economy indicators has dependent on the fundamental cause of the oil price shock, that is, whether oil price variations are motivated by shifts in oil demand or supply. Moreover, the paper find that the explicit cause of the oil price shock distresses the size and nature of the responses of foremost Indian macroeconomic aggregates. In specific, when an increase in oil prices is instigated by an oil supply disorder in India with this an insistent to deterioration in its GDP and a rise in the CPI inflation. The outcome of the table no -4 has revealed that the Indian Government debt volatility is mostly elucidated by foreign oil intensity shocks as these shocks cause main lead to create the fluctuations in Indian Government revenue. And the study found that the overseas oil shocks are the highest responsible of Indian crude oil price fluctuation. Further This research paper examined the impact of crude oil price shockwaves on the eight macroeconomic variables i.e. GDP, IIP, WPI, real output, real exchange rate interest rate and inflation using Structural Vector Autoregressive (SVAR) model during period from 2010 to 2018.

The study suggest that the oil price shocks have significant negative impact is there on Indian economic development activity in short and long run. However, it has perceived that each variable in a paper has given different response on crude oil price fluctuation. Variations in the results of these four variables may be accredited to their policies, macroeconomic essentials. This paper provides certain policy recommendations for Indian economist and policy maker. Initially, practically all macroeconomic variables (real GDP, interest rate, inflation and real exchange rate) under consideration of this research paper significant change had been there due to crude oil price fluctuation in short and long run time period to Indian economy. In this point the study strongly suggested that the government of Indian should take the realistic measures to avoid exogenous effects of crude oil prices. For that intention, Indian Government should suggest the energy consumption policy and implement new technologies that use unconventional energy so that they can expedite and invite domestic and as well as foreign direct investments in the India.

\section{References}


1. Bhattacharya, Kaushik, Bhattacharya, \& Indranil (2001) 'Impact of Increase in Oil Prices on Inflation and Output in India', Economic and Political Weekly, Vol.36, No.51, pp 4735-4741.

2. Darby \& Michael R (1982), "The Price of Oil and World Inflation and Recession," American Economic Review, American Economic Association, vol. 72(4), pages 73851, September.

3. Hamilton James D. (1996): "This is what happened to the oil price-macroeconomy relationship," Journal of Monetary Economics, Elsevier, vol. 38(2), pages 215-220, October

4. Hilde C. Bjørnland (2009): "Oil Price Shocks and Stock Market Booms in an Oil Exporting Country," Scottish Journal of Political Economy, Scottish Economic Society, vol. 56(2), pages 232-254, 05

5. Hidhayathulla A. \& Mahammad Rafee. B. (2014): "Relationship between crude oil price and Rupee, Dollar Exchange Rate: An Analysis of Preliminary Evidence," IOSR Journal of Economics and Finance, vol3, issue 2, ver. II, pages 01-04

6. Kaushik N., Nag R., \& Upadhyaya K. P. (2014): “Oil Price and Real Exchange Rate: The Case of India," International Business and Economics Research Journal, volume 13 , no. 4

7. Kim S., \& Roubini N. (2000): Exchange rate anomalies in the industrial countries: A solution with a structural VAR approach, Journal of Monetary Economics, Vol. 45(3), pp.561-586

8. Barnett, W. A., Bhadury, S. S. \& Ghosh, T. (2016) “A SVAR Approach to Evaluation of Monetary Policy in India," Open Economies Review, FMND Special Issue (forthcoming)

9. Kim, K. S. (2005). Impacts of Foreign Shocks onDomestic Macroeconomic Fluctuations Policy References 05-06.

10. Lee, K., Ni, S., \& Ratti, R. A. (1995). Oil shocks and the macroeconomy: the role of price variability. The Energy Journal, 39-56.

11. Edelstein, P., \& Kilian, L. (2009). How sensitive are consumer expenditures to retail energy prices? Journal of Monetary Economics, 56(6), 766-779.

12. Raza, N., Shahzad, S. J. H., Tiwari, A. K., \& Shahbaz, M. (2016). Asymmetric impact of gold, oil prices and their volatilities on stock prices of emerging markets. Resources Policy, 49, 290-301.

13. Chang, Y. \& J.F. Wong (2003) 'Oil Price Fluctuations and Singapore Economy', Energy Policy 31(11): 1151-1165.

14. Ahmad, F. (2013) 'The Effect of Oil Prices on Unemployment: Evidence from Pakistan' Business and Economics Research Journal, Vol. 4 No.1, pp. 43-57.

15. Ahmad, W. \& Kamaiah, B. (2010) 'Modeling Business Cycles in India: A Markov Switching Approach', The Asian Economic Review, Vol. 52, No. 2.

16. Brown, S. P. A. \& Yucel, M. K. (2002) 'Energy prices and aggregate economic activity: an interpretative survey', The Quarterly Review of Economics and Finance, Vol.42, No. 2, pp. 193-208.

17. Ewing, B. T. \& Thompson, M. A. (2007) 'Dynamic cyclical comovements of oil prices with industrial production, consumer prices, unemployment, and stock prices', Energy Policy, Vol. 35, pp. 5535-5540.

18. Ozlale, U. \& Pekkurnaz, D. (2010) 'Oil prices and current account: A structural analysis for the Turkish economy', Energy Policy, Vol. 38, pp. 4489-4496.

19. Hassan, S. A. \& Zaman, K. (2012) 'Effect of oil prices on trade balance: New insights into the cointegration relationship from Pakistan', Economic Modelling, Vol. 29, pp. 2125-2143. 
20. Zhang, Y.-J. \& Wei, Y.-M. (2010) 'The crude oil market and the gold market: Evidence for cointegration, causality and price discovery', Resources Policy, Vol. 35, No.3, pp. 168-177

21. Jain, A. \& Ghosh, S. (2013) 'Dynamics of global oil prices, exchange rate and precious metal prices in India', Resources Policy, Vol. 38, pp. 88-93.

22. Jungwook, P. \& Ronald, A. R. (2008). Oil price shocks and stock markets in the U.S. and 13 European Countries. Energy Economics, 30, p 2587-608.

23. Maghyereh, A. (2004). Oil price shocks and emerging stock markets. A generalized VAR approaches. International Journal of Applied Econometrics and Quantitative Studies, 1(2), 27-40

24. Kapil, J. (2013). Oil price volatility and its impact on the selected Economic indicators in India. International Journal of Management and Social Sciences Research (IJMSSR), 2(11).

25. Ready \& Robert, C. (2013). Oil prices and long-run risk, working paper. Routledge, Bryan R., Duane J. Seppi, and Chester S. Spatt, 2000, Equilibrium forward curves for commodities. The Journal of Finance, 55, 1297-338.

26. Jones, C. M., \& Kaul, G. (1996). Oil and the stock markets. Journal of Finance 51, 463-491.

27. Ono, S. (2011). Oil price shocks and stock markets in BRICs. The European Journal of Comparative Economics 8, 29-45.

28. Papapetrou, E. (2001). Oil price shocks, stock market, economic activity and employment in Greec. Energy Economics 23, 511-532.

29. Park, J., \& Ratti, R. A. (2008). Oil price shocks and stock markets in the US and 13 European countries. Energy Economics, 30, 2587-2608.

30. Sadorsky, P. (1999). Oil shocks and stock markets activity. Energy Economics 21, 449469. 